\title{
Role of Fluids in Origin PGE Mineralization's in the Pansky Tundra Layered Intrusion, Kola Peninsula, NW Russia
}

\section{Turchenko SI*}

Institute of Precambrian Geology and Geochronology, Russian Academy of Sciences, Russia

\section{Opinion}

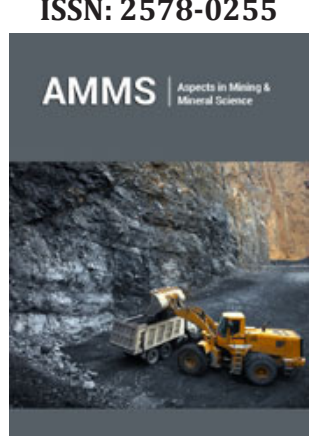

*Corresponding author: Turchenko SI, Institute of Precambrian Geology and Geochronology, Russian Academy of Sciences, Russian Federation, Russia

Submission: 海 August 22, 2019

Published: 觜October 15, 2019

Volume 3 - Issue 5

How to cite this article: Turchenko SI. Role of Fluids in Origin PGE Mineralization's in the Pansky Tundra Layered Intrusion, Kola Peninsula, NW Russia. Aspects Min Miner Sci.3(5). AMMS.000574.2019. DOI: 10.31031/AMMS.2019.03.000574

Copyright@ Turchenko SI, This article is distributed under the terms of the Creative Commons Attribution 4.0 International License, which permits unrestricted use and redistribution provided that the original author and source are credited.
The Pansky Tundra layered intrusion belongs to a group of the Paleo Proterozoic layered intrusions (2.45-2.50Ga) located in the north-eastern Fennoscandian Shield, Kola Peninsula (Russia). The intrusions were emplaced during just that epoch of intracontinental rifting. This intrusion consists of norite-gabbronorite-gabbroic megacycles and contain rhythmically layered horizon (up to 200-300m thick). This last includes thin "layers" of norite, olivinegabbronorite, melanonorite, troctolite and sill-like pyroxene anorthosite. Namely the pyroxene anorthosite lenses host low sulphide Ni-Cu and PGE mineralization and strongly metasomatic altered. The U-Pb ages of gabbronorite by zircon is $2470+\backslash-9 \mathrm{Ma}$ and anorthosites by baddeleyite is $2449+\backslash-12 \mathrm{Ma}$. Ore-bearing pyroxene anorthosite lenses have $10-100$ meters long and $10-30 \mathrm{~cm}$ thick. Nonaltered rocks consist of plagioclase $(75 \mathrm{An})$ accumulate with intercumulus pyroxene (up to $5 \%$ ) and quartz. With ore-bearing anorthosites associate «mixed» rocks which consist of plagioclase accumulate and dark irregular plagioclasebronsite cumulate and have similar features to the "raisin pudding" anorthosite in the J-M Reef or PGE reef in the Penikat intrusion, Finland. Ore-bearing altered pyroxene anorthosites are composed by two successively-formed metasomatic association: 1) replacement of pyroxene by tremolite and magnetite; 2) epidote-zoisite-chlorite-albite-sericite-quartz association in the paragenesis with the sulphide-PGE mineralization. The PGE (tellurides, bismutides and sulphides of Pd and Pt) minerals closely associate with chalcopyrite and pentlandite and are rarely hosted within pyrrhotite and bornite grains. Comparing with host gabbronorites, the REE patterns of ore-bearing anorthosites are characterized by positive Eu-anomaly and lower contents of HREE. Mineralised rocks are clearly enriched by $\mathrm{Te}, \mathrm{Au}, \mathrm{Se}, \mathrm{Ir}, \mathrm{Cu}, \mathrm{Ag}, \mathrm{Ni}$ and especially of $\mathrm{Br}, \mathrm{Cl}$ (neutron-activation analysis) in the relation to an average gabbronorite of the Pansky Tundra intrusion. Simultaneously for these rocks are typical a sharp depletion in $\mathrm{Cr}$ content. Mass-spectrometric thermion-emission study of fluid phases in altered anorthosites and gabbronorites shows that most part of $\mathrm{H}_{2} \mathrm{O}, \mathrm{N}_{2}, \mathrm{SO}_{2}$ and $\mathrm{CO}, \mathrm{CH}_{4}$ gases were extracted within temperature interval $800-1200{ }^{\circ} \mathrm{C}$ as well as its higher content comparably with host gabbronorites.

The occurrence PGE minerals and sulphides in the paragenesis with hydroxyl-bearing silicates in metasomatic altered anorthosites can indicate high temperature hydrothermal origin of the PGE mineralization in the Pansky Tundra layered intrusion. Such correlations are typical also for large layered plutons, such as Sudbury or even for Alpine-type ultramafic intrusions. The data do not support a simple «magmatic model», but rather argue in favour to late magmatic high temperature hydrothermal origin of PGE ores and sulphide mineralization close to crystallisation of most later vapour-saturated anorthosite within rhythmically layered horizons. 